\title{
Ghrelin: a hypothalamic GH-releasing factor in domestic fowl (Gallus domesticus)
}

\author{
S Ahmed and S Harvey \\ Department of Physiology, University of Alberta, Edmonton, Alberta T6G 2H7, Canada \\ (Requests for offprints should be addressed to S Harvey; Email: steve.harvey@ualberta.ca)
}

\begin{abstract}
Ghrelin, a recently discovered peptide in the mammalian hypothalamus and gastrointestinal tract is thought to be the endogenous ligand for the GH secretagogue (GHS) receptor and it stimulates $\mathrm{GH}$ release in rats and humans. The possibility that ghrelin is present in birds was therefore assessed, since a GHS receptor is present in the chicken pituitary gland.

Although immunoreactive ghrelin is readily detectable in the rat stomach and ileum, ghrelin immunoreactivity could not be detected in the chicken proventriculus, stomach, ileum or colon, whereas somatostatin immunoreactivity, in contrast and as expected, was readily detectable in the chicken gastrointestinal tract. Ghrelin immunoreactivity was, however, present in the chicken hypothalamus, although not in the arcuate (infundibular) nucleus, as in rats. Discrete parvocellular cells and neuronal fibers with ghrelin immunoreactivity were present in the anterior medial hypothalamus. This immunoreactivity was specific and completely abolished following the preabsorption of the antibody with an excess of human
\end{abstract}

ghrelin. Ghrelin immunoreactivity was also present in clusters of large ovoid magnocellular cells in the nucleus magnocellularis preopticus pars medialis, nucleus magnocellularis preopticus supraopticus and in the chiasmaopticus. Immunoreactivity for ghrelin was restricted to the cytoplasm of the perikarya and their axonal sprouts. Immunoreactivity for ghrelin was not seen in any other hypothalamic nuclei.

In a preliminary experiment, circulating $\mathrm{GH}$ concentrations in conscious immature chicks were promptly increased following bolus i.v. administration of human ghrelin. The increase in GH concentration (approximately three times that in the controls) was comparable with that induced by the same dose $(10 \mu \mathrm{g} / \mathrm{kg})$ of human GHreleasing hormone, although less than that (approximately sixfold) induced by thyrotropin-releasing hormone.

These results demonstrate the presence of a ghrelin-like protein in the chicken hypothalamus and suggest that it participates in the regulation of $\mathrm{GH}$ secretion in birds.

Journal of Endocrinology (2002) 172, 117-125

\section{Introduction}

Growth hormone (GH) secretion is regulated by a myriad of interacting, multihierarchical factors that dynamically modify somatotroph function at neural and humeral interfaces in neurocrine, neuroendocrine, endocrine and paracrine ways (Harvey 1995). The hypothalamus is, however, thought to primarily regulate $\mathrm{GH}$ release in mammals through antagonistic interactions between stimulatory (GH-releasing hormone; GHRH) and inhibitory (somatostatin; SRIF) hypophysiotropic-releasing hormones. A third hypothalamic factor, ghrelin, may also be involved (Dieguez \& Casanueva 2000, Kojima et al. 2001), since it is present in the arcuate nucleus of the mouse, rat and human hypothalamus (Kojima et al. 1999, Hosoda et al. $2000 a$, Korbonits et al. 2001) and is three to five times more potent than GHRH in stimulating GH release in these species (Kojima et al. 1999, Arvat et al. 2000, Seoane et al. 2000). It is, however, not known if ghrelin is involved in $\mathrm{GH}$ regulation in other species.
In birds, the control of $\mathrm{GH}$ secretion differs from that in mammals, since chicken GHRH has minimal GHreleasing activity in chickens (Harvey 1999) and because thyrotropin-releasing hormone (TRH) is a potent $\mathrm{GH}-$ releasing factor (Harvey 1990). The possibility that ghrelin may participate in $\mathrm{GH}$ release in birds was therefore assessed, especially as ghrelin is thought to be the endogenous ligand for a GH secretagogue (GHS) receptor identified in chicken pituitary glands (Toogood et al. 1999, Gaylinn et al. 2000).

\section{Materials and Methods}

\section{Immunocytochemistry}

White Leghorns at 4 weeks of age were killed by cervical dislocation (with approval from the University of Alberta Health Sciences Animal Welfare Committee) and hypothalami were rapidly dissected from the heads, washed in 
ice-cold phosphate-buffered saline (PBS; $\mathrm{pH} 7 \cdot 4$ ) and collected into freshly prepared paraformaldehyde (4\% w/v) (Sigma, Mississauga, Ontario, Canada). The hypothalami were removed in one piece, with two parallel cuts $2 \cdot 0-2.5 \mathrm{~mm}$ lateral to the midline, a transverse cut in front of the preoptic area and the roots of the oculomotor nerves and a cut $4-5 \mathrm{~mm}$ deep parallel to the base of the brain (MacNamee \& Sharp 1989). After overnight fixation, at $4{ }^{\circ} \mathrm{C}$, the tissues were dehydrated in a graded series of alcohol (50\% v/v, 15-30 min; 70\%, 30-60 min; 95\%, 30-60 min; 100\%, 30-60 min) and cleared with hemo-de (Fisher Scientific, Edmonton, Alberta, Canada) for $30 \mathrm{~min}$. Tissues were then infiltrated with paraffin wax for $24 \mathrm{~h}$ at $60^{\circ} \mathrm{C}$, under normal atmospheric pressure. Serial transverse sections $(4-8 \mu \mathrm{m})$ were cut with a microtome and mounted onto treated slides (Fisher Scientific). The sections were cut anterior-dorsally, using co-ordinates A10.0 to A5.6, according to the histological atlas of Kuenzel \& Masson (1988). Magnocellular nuclei were identified according to Yasuda (1980) and Mikami (1985).

Immunocytochemical staining was performed with commercial reagents (Vector Laboratories, Burlington, CA, USA and Sigma), using an avidin-biotin-peroxidase (ABC) (Hsu et al. 1981) method. Sections were incubated with a specific commercial antibody raised in rabbits against rat ghrelin (RAB-031-31; Phoenix Pharmaceuticals, Belmont, CA, USA), with which human ghrelin has $100 \%$ cross-reactivity. The primary antibody was diluted 1:500 in 1-5\% normal goat serum, overnight, at $4{ }^{\circ} \mathrm{C}$. After incubation, the slides were washed three times for $15 \mathrm{~min}$ in PBS. Sections were then incubated for $1 \mathrm{~h}$ at room temperature in biotinylated goat anti-rabbit immunoglobulin G (Sigma; 1:200). The slides were washed in PBS and incubated in $\mathrm{ABC}$ reagent for $1 \mathrm{~h}$ at room temperature and washed in PBS. Staining was visualized using the chromogenic substrate diaminobenzidine tetrahydrochloride (Sigma), which resulted in a brown coloration. The specificity of staining was determined by preabsorbing the primary antibody with synthetic human ghrelin (Phoenix Pharmaceuticals; $1 \mathrm{mg} / \mathrm{ml}$ ) for $1 \mathrm{~h}$ prior to section incubation. Non-specific staining was determined by replacing the primary antibody with pre-immune rabbit serum or with PBS or by omission of the secondary antibody. As a positive control (Kojima et al. 1999), sections of the rat stomach were similarly stained for ghrelin immunoreactivity. Sections of the chick stomach and gastrointestinal tract were similarly stained for SRIF immunoreactivity, using an antibody raised in rabbits against $\mathrm{SRIF}_{14}$ (Di ScalaGuenot et al. 1984) at a dilution of 1:200, since SRIF immunoreactivity has been found throughout the chicken gastrointestinal tract (Denbow 2000).

\section{GH-releasing activity}

The GH-releasing activity of human ghrelin (Phoenix Pharmaceuticals) was assessed in conscious 4-week-old
White Leghorn chicks, in comparison with human $\mathrm{GHRH}_{1-44}$ and TRH (Bachem, Torrance, CA, USA). Groups of birds $(n=8-16)$ were given a bolus i.v. injection of peptide or the $0.9 \%(\mathrm{w} / \mathrm{v}) \mathrm{NaCl}$ vehicle $(1 \mathrm{ml} / \mathrm{kg}$ body weight). Each peptide was administered at a dose of $10 \mu \mathrm{g} / \mathrm{kg}$, since this is the maximally effective dose of TRH and GHRH in chickens (Harvey \& Scanes 1984) and is comparable to doses of ghrelin that stimulate $\mathrm{GH}$ release in rats $(4-20 \mu \mathrm{g} / \mathrm{kg}$ in rats, Hosoda et al. 2000b) and humans $(5 \mu \mathrm{g} / \mathrm{kg}$, Takaya et al. 2000; 33-66 $\mu \mathrm{g} / \mathrm{kg}$, Peino et al. 2000). Venous blood samples were collected from each bird $10 \mathrm{~min}$ after injection, at the time of the maximal GH response to TRH and GHRH (Harvey \& Scanes 1984).

Following centrifugation and separation, the plasma was stored at $-20{ }^{\circ} \mathrm{C}$ prior to $\mathrm{GH}$ radioimmunoassay, using NIADD reagents (Bethesda, MD, USA, kindly provided by Dr A F Parlow). Statistical differences in the results were determined by analysis of variance.

\section{Results}

\section{Immunohistochemistry}

As expected (Kojima et al. 1999, Date et al. 2000a), ghrelin immunoreactivity was abundantly present within the X/A-like endocrine cells of the rat stomach (Fig. 1A and C). Staining was completely abolished following the preabsorption of the antiserum with human ghrelin (Fig. 1B). In contrast, sections of the chicken stomach (and the proventriculus, ileum and colon) had no ghrelin immunoreactivity (data not shown), but were stained for SRIF immunoreactivity (Fig. 1D and F). In the hypothalamus, ghrelin immunoreactivity was present in discrete cells in the nucleus anterior medialis hypothalami (AM) (Fig. 2A-C and Fig. 4), and was also present in clusters of large ovoid cells in the nucleus magnocellularis preopticus pars medialis (PRM) (Fig. 2A, E and F and Fig. 4), nucleus magnocellularis preopticus pars supraopticus (PRS) (Fig. $3 \mathrm{~A}, \mathrm{E}$ and $\mathrm{F}$ and Fig. 4) and in the chiasma opticus (CO) (Fig. 3A-C and Fig. 4). Immunoreactivity for ghrelin was restricted to the cytoplasm of the perikarya and their axonal sprouts. Ghrelin staining was lost following the preabsorption of the antibody with human ghrelin (Fig. 2D and Fig. 3D) and not seen when the ghrelin antibody was replaced by normal rabbit serum or PBS (data not shown). Immunoreactivity for ghrelin was not present in any other hypothalamic nuclei.

\section{GH-releasing activity}

Circulating $\mathrm{GH}$ concentrations in conscious, immature chicks were promptly increased $(P<0 \cdot 001)$ following the i.v. administration of human ghrelin (Fig. 5). The increase in $\mathrm{GH}$ concentration (approximately three times that in 

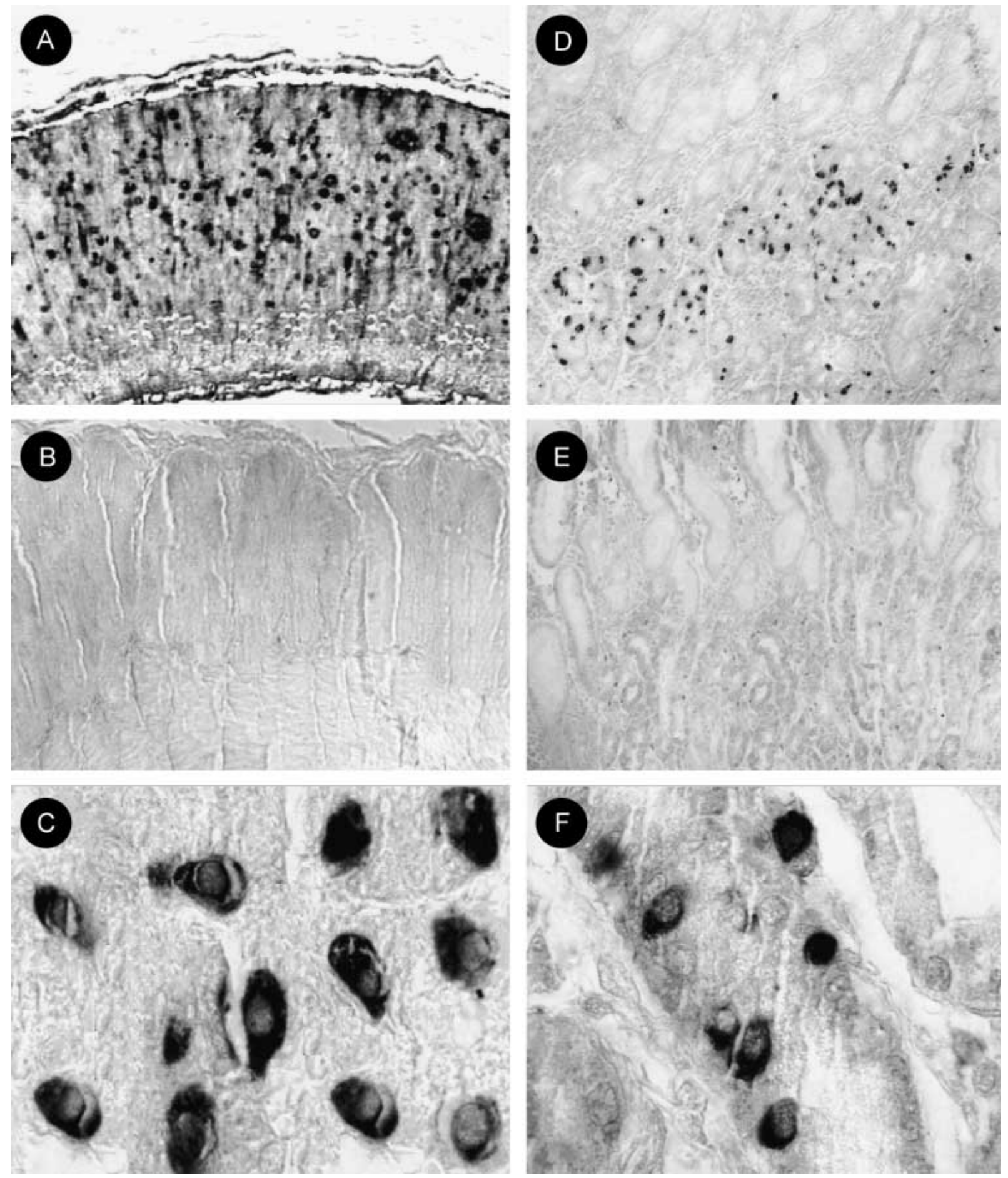

Figure 1 (A) Ghrelin immunoreactivity in the rat stomach $(\times 100)$. (B) Ghrelin immunoreactivity is lost following preabsorption of the primary antibody with excess human ghrelin $(\times 100)$. (C) X/A-like endocrine cells are strongly stained for ghrelin immunoreactivity $(\times 1000)$. (D) SRIF immunoreactivity in the chick stomach $(\times 100)$. (E) SRIF immunoreactivity is lost following omission of the primary antibody $(\times 100)$. $(F)$ Higher magnification of the SRIF-immunoreactive cells in the chich stomach $(\times 1000)$. 

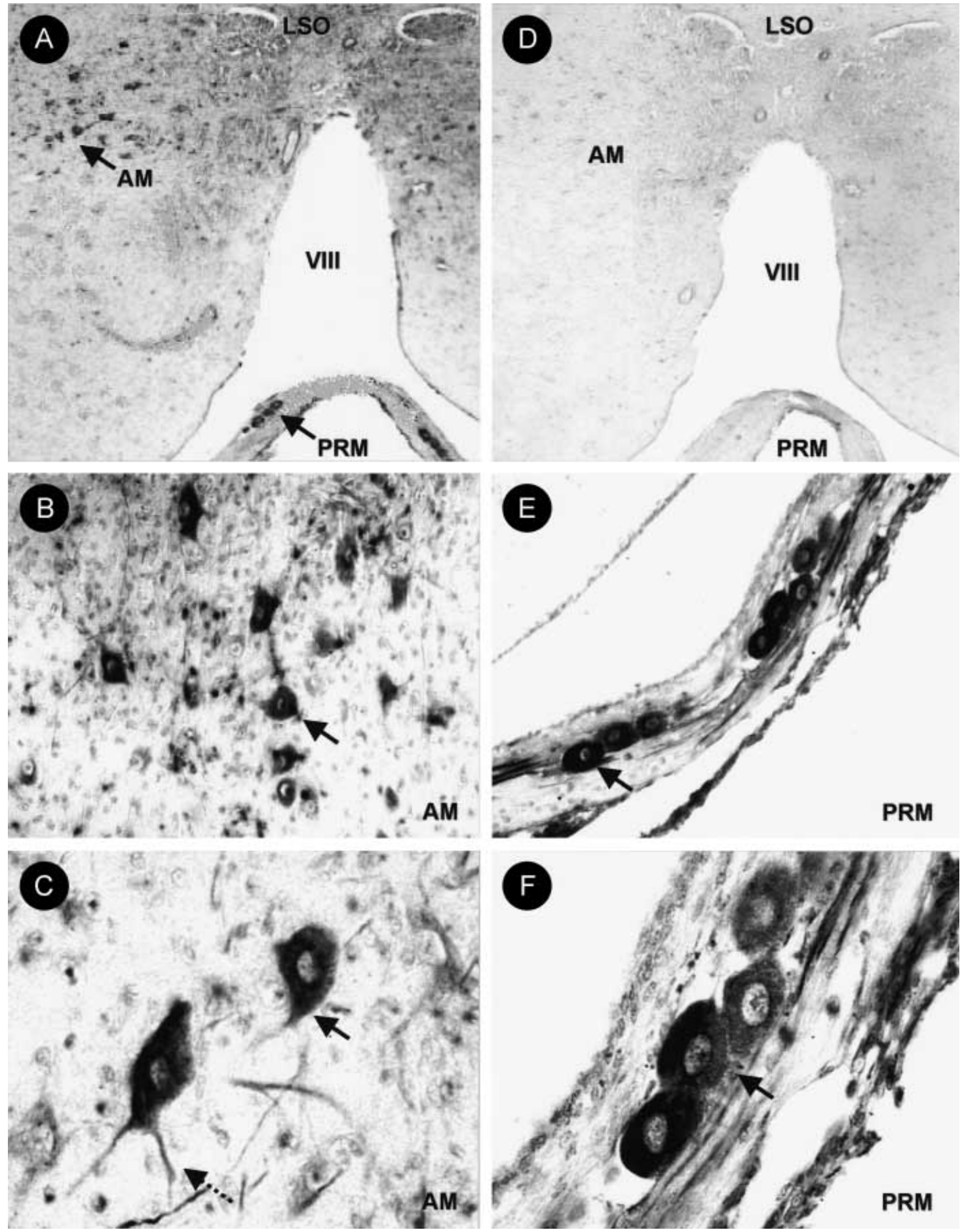

Figure 2 Distribution of ghrelin immunoreactivity in perikarya and fibers in the chick hypothalamus. (A) Ghrelin immunoreactivity in the AM and PRM $(\times 100)$. (B and C) Magnification of the AM $(\times 400$ and $\times 1000$ respectively). (D) Immunoreactive staining in the AM and PRM was lost following the preabsorption of the primary antibody with excess human ghrelin $(\times 100)$. (E and F) Magnification of the PRM $(\times 400$ and $\times 1000$ respectively). Solid arrows indicate stained perikarya whilst the dotted arrow indicates immunoreactive fibers. LSO, organum septi laterale; VIII, third ventricle. 

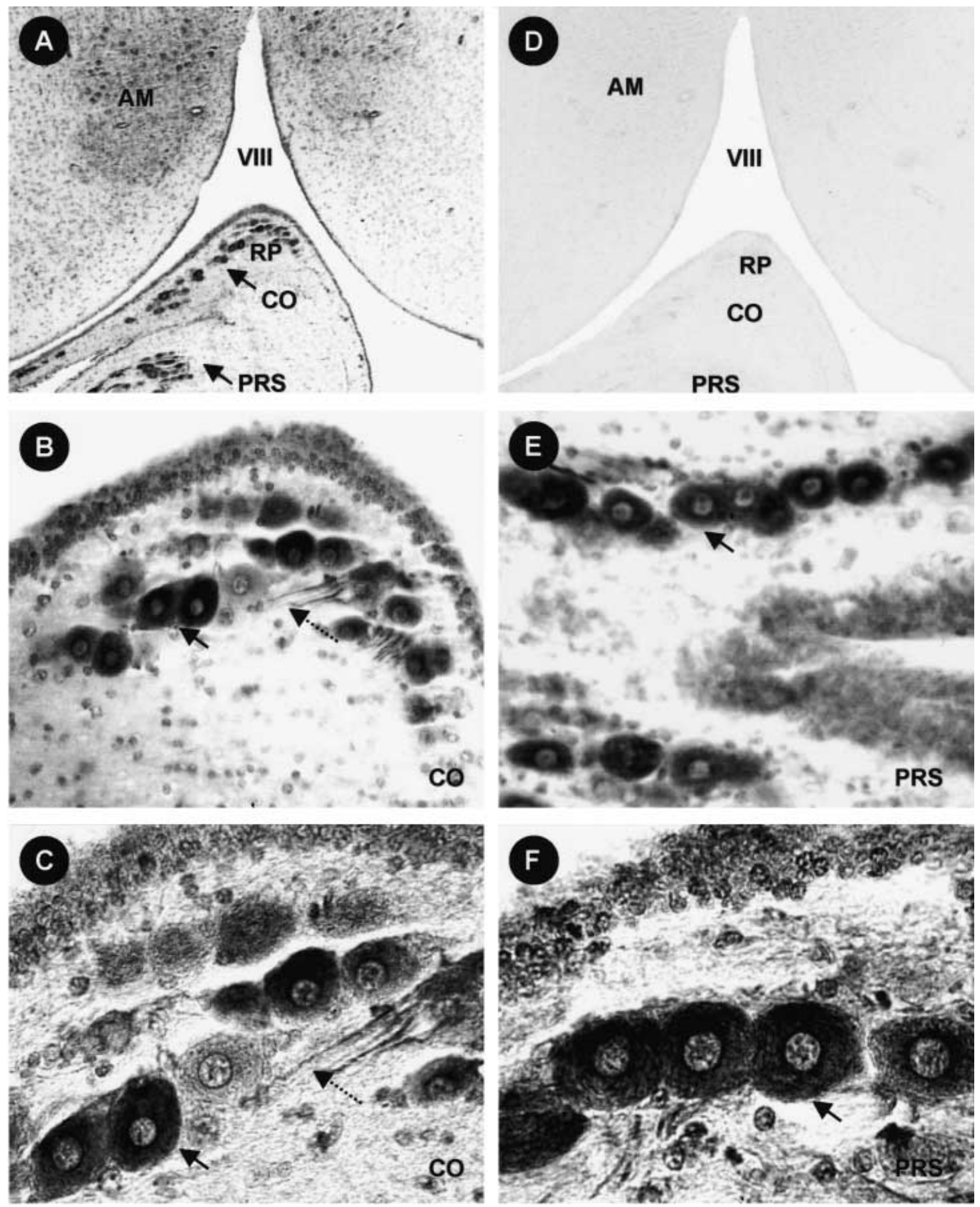

Figure 3 Distribution of ghrelin immunoreactivity in perikarya and fibers in the chick hypothalamus. (A) Ghrelin immunoreactivity in the CO and PRS $(\times 100)$. (B and C) Magnification of the CO $(\times 400$ and $\times 1000$ respectively). (D) Immunoreactive staining in the CO and PRS is lost following preabsorption of the primary antibody with excess human ghrelin $(\times 100)$. (E and F) Magnification of the PRS $(\times 400$ and $\times 1000$ respectively). Solid arrows indicate stained perikarya whilst dotted arrows indicate immunoreactive fibers. RP, recessus preopticus. 


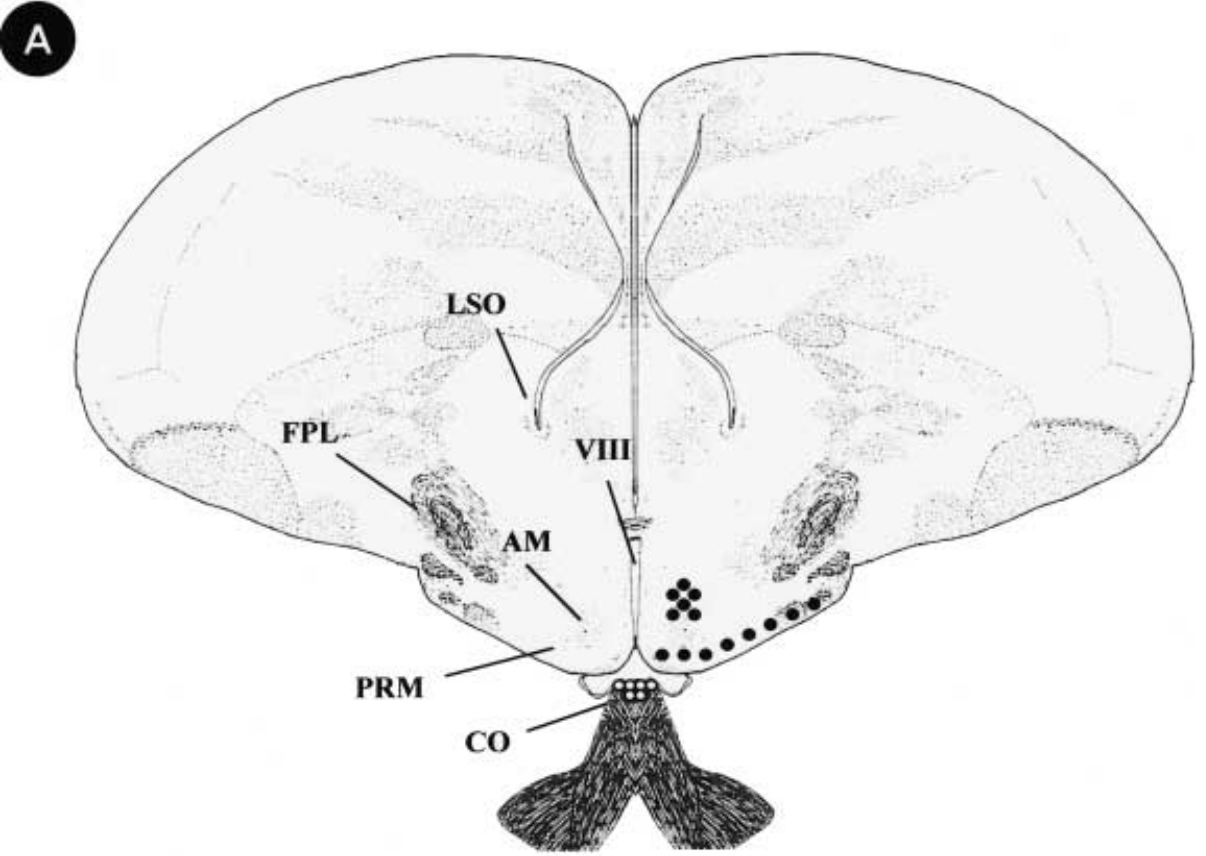

B

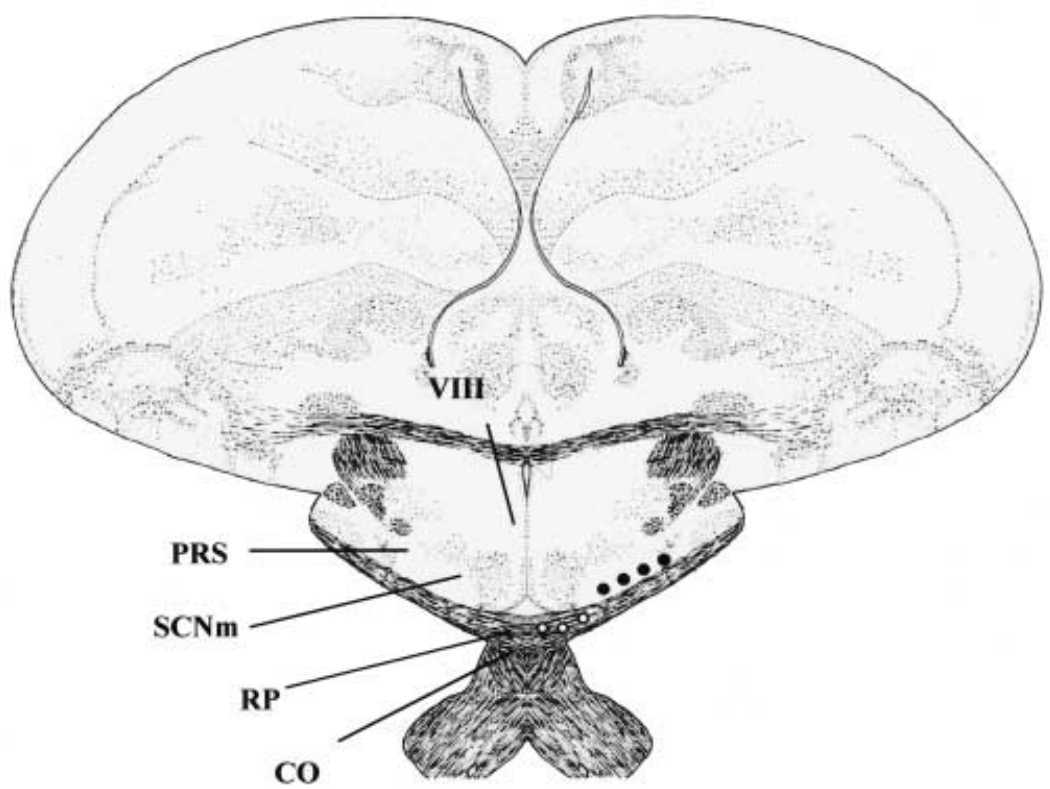

Figure 4 Ghrelin immunoreactivity in the chick hypothalamus. (A) Schematic illustration of the location of immunostained cell bodies (solid and open circles) in the AM and in magnocellular cells in the PRM. (B) Schematic illustration of the location of immunostained cell bodies (solid and open circles) in magnocellular cells in the CO and PRS. SCNm, nucleus suprachrasmaticus, pars medialis; $\mathrm{FPL}$, fasciculus prosencephali lateralis (lateral forebrain bundle); LSO, organum septi laterale (lateral septal organ). Based on the histological atlas of Kuenzel \& Masson (1988). 


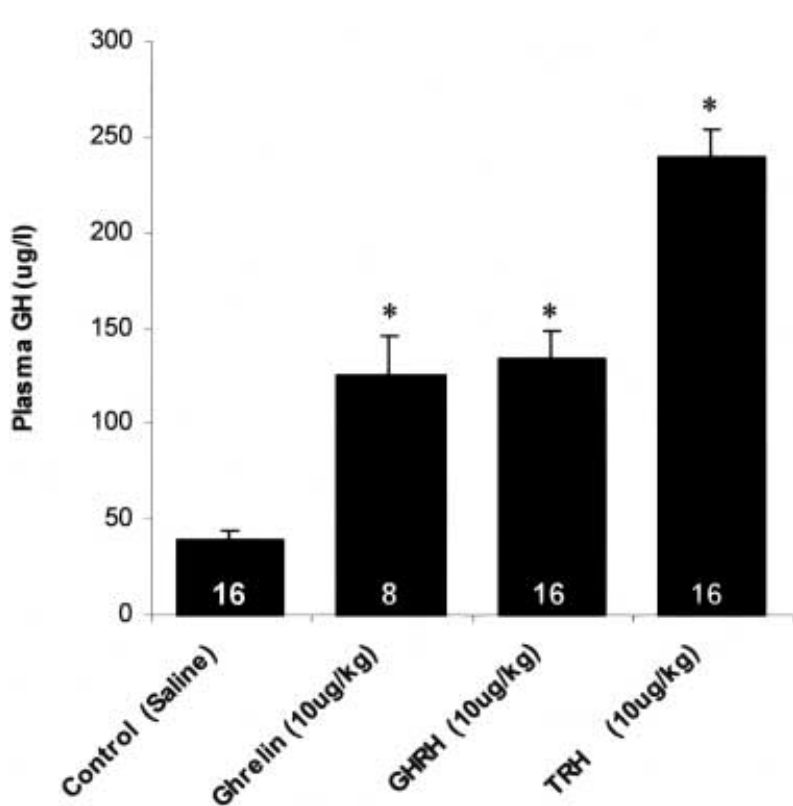

Figure 5 Plasma GH in 4-week-old chicks 10 min after the i.v. injection of ghrelin, GHRH or TRH (all at $10 \mu \mathrm{g} / \mathrm{kg}$ body weight), in comparison with controls injected with the $0.9 \% \mathrm{NaCl}$ vehicle $(1 \mathrm{ml} / \mathrm{kg}) .{ }^{*} P<0 \cdot 01$ compared with the controls. Numbers in each group are indicated in the bars. Values are means \pm S.E.M.

the controls) was comparable with that induced by the same dose $(10 \mu \mathrm{g} / \mathrm{kg})$ of human GHRH, although less $(P<0 \cdot 01)$ than that (approximately sixfold) induced by TRH.

\section{Discussion}

These results demonstrate, for the first time, a stimulatory effect of human ghrelin on GH secretion in the chicken. The prompt GH-releasing activity of human ghrelin was comparable to that induced by the same dose $(10 \mu \mathrm{g} / \mathrm{kg})$ of human GHRH, although of lesser magnitude than that induced by TRH (on a weight basis). Additional dose- and time-course studies, on a molar basis, are required to fully characterize its role as a GHS in birds, but it is of interest that activation of the GHS (ghrelin) receptor by two non-peptidyl mimics (L-692,429 and L-163,225) also promptly increased GH secretion in the chicken (Geris et al. 1998, 2001).

The stimulation of GH secretion by ghrelin could result from a direct pituitary action. Indeed, the presence of a GHS (ghrelin) receptor in the chick pituitary gland (Toogood et al. 1999, Gaylinn et al. 2000), the stimulatory actions of the peptidomimetics on GH release from perifused chicken pituitary glands (Geris et al. 2000, 2001) and the ability of ghrelin to induce $\mathrm{GH}$ release from rat pituitary glands in vitro (Kojima et al. 1999) support this possibility.
The results of the present study also demonstrate, for the first time, the presence of a ghrelin-like protein in a non-mammalian species, with cross-reactivity with rat and human ghrelin. Ghrelin-like immunoreactivity in the chick was, however, in dissimilar locations to its presence in mammals. In rats and humans, ghrelin is primarily found in the stomach and gastrointestinal tract (Kojima et al. 1999, 2001, Date et al. 2000a), although it is also present in the arcuate nucleus (Kojima et al. 1999, Korbonits et al. 2001). In the chick, ghrelin immunoreactivity could not be detected in the stomach, duodenum, ileum or colon, even though SRIF immunoreactivity (as expected, Denbow 2000) was clearly present. This restriction of ghrelin immunoreactivity to the hypothalamus of the chick suggests that it evolved phylogenetically as a neuropeptide rather than as a gastrointestinal hormone.

Although ghrelin immunoreactivity was found in parvocellular cells in the hypothalamus, it was not in the arcuate nucleus (infundibular nucleus) as in rats and humans, but in discrete populations in the AM. Since parvocellular cells in the hypothalamus are thought to terminate on portal blood vessels in the median eminence, the presence of ghrelin in the AM suggests that it may be a hypophysiotropic releasing factor and stimulate pituitary GH release after secretion into the hypothalamohypophysial circulation. Furthermore, as GH has recently been discovered in the AM (Ramesh et al. 2000), ghrelin may also have roles in the autocrine or paracrine regulation of GH synthesis or release within the brain.

In addition to the AM, ghrelin immunoreactivity was also found in magnocellular cells in the ventromedial hypothalamus (in the PRM and PRS (derived from the supraoptic nucleus) and in the CO). This is the first demonstration of ghrelin in magnocellular cells. The presence of ghrelin in these cells therefore resembles the presence of arginine vasotocin and mesotocin in the chicken hypothalamus (Tennyson et al. 1985, Robinzon et al. 1988, Barth et al. 1997). Fibers from these cells have been shown to extend to the avian median eminence (Mikami 1985, Tennyson et al. 1985, Robinzon et al. 1988) and it is therefore possible that ghrelin stimulates pituitary $\mathrm{GH}$ after release from these fibers into the hypophysial portal circulation. Most magnocellular neurons do not, however, terminate in the median eminence but in the neurohypophysis. Ghrelin-induced GH secretion in the chick may thus be indirect and mediated by release into the short portal vessels connecting the pars nervosa with the pars distalis. Although indirect, this route is commonly utilized for transporting hypothalamic releasing factors to the adenohypophysis in non-primate species (Anthony et al. 1998).

In addition to a pituitary site of action, ghrelin-induced GH secretion could also be mediated centrally. Indeed, ghrelin has been shown to rapidly (within $10 \mathrm{~min}$ ) stimulate $\mathrm{GH}$ secretion in rats through an inhibition of hypothalamic somatostatin release (Date et al. 2000b, Tolle 
et al. 2001, Wren et al. 2000). Hypothalamic actions of ghrelin on fos-, erg-1, agouti-related protein and neuropeptide Y transcription (Hewson \& Dickson 2000, Nakazato et al. 2001) and food intake (Kamegai et al. 2000, Masuda et al. 2000, Tschop et al. 2000, Nakazato et al. 2001, Shintani et al. 2001) are also well established, reflecting the widespread distribution of ghrelin receptors in the central nervous system (CNS) (Howard et al. 1996, Guan et al. 1997, McKee et al. 1997). The GH-releasing activity of human ghrelin in the chicken may, thus, be partially mediated by actions at CNS sites, especially as the non-peptidyl mimetics of GHS receptors partially stimulate GH release in chicks by rapidly increasing hypothalamic TRH release (Geris et al. 1998, 2001). The stimulatory effects of GHRH and TRH on GH secretion in the chick are similarly partially mediated by actions within the CNS (Harvey 1990, 1999). The possibility that ghrelin acts within the CNS is also supported by its ability to act at central sites to modulate food intake in the fowl (Furuse et al. 2001).

In summary, these results demonstrate the presence of ghrelin immunoreactivity in neurons of the chicken hypothalamus and stimulatory actions of ghrelin on $\mathrm{GH}$ secretion in the chick.

\section{Acknowledgements}

The authors would like to thank Dr A F Parlow for providing immunoreagents for the $\mathrm{GH}$ assay, Dr M-T Strosser for the SRIF antibody, and the NSERC of Canada for financial support.

\section{References}

Anthony EL, Overdeep PA, Bruhn TO \& Gustafson AW 1998 Evidence for diverse pathways of hypophysiotropic hormone transport in mammals. Comparative Biochemistry and Physiology 119 365-374.

Arvat E, Di Vito L, Broglio F, Papotti M, Muccioti G, Dieguez C, Casanueva FF, Deghenghi R, Camanni F \& Ghigo E 2000 Preliminary evidence that ghrelin, the natural GH secretagogue (GHS) receptor ligand, strongly stimulates $\mathrm{GH}$ secretions in humans. Journal of Endocrinological Investigation 23 493-495.

Barth SW, Bathgate RA, Mess A, Parry LJ, Ivell R \& Grossmann R 1997 Mesotocin gene expression in the diencephalon of domestic fowl: cloning and sequencing of the MT cDNA and distribution of MT gene expressing neurons in the chicken hypothalamus. Journal of Neuroendocrinology 9 777-787.

Date Y, Kojima M, Hosoda H, Sawaguchi A, Mondal M, Suganuma T, Matsukura S, Kangawa K \& Nakazato M 2000a Ghrelin, a novel growth hormone-releasing acylated peptide, is synthesized in a distinct endocrine cell type in the gastrointestinal tracts of rats and humans. Endocrinology 141 4255-4261.

Date Y, Murkami N, Kojima M, Kuroiwa T, Matsukura S, Kangawa K \& Nakazato M $2000 b$ Central effects of a novel acylated peptide, ghrelin, on growth hormone release in rats. Biochemical and Biophysical Research Communications 275 477-480.

Denbow DM 2000 Gastrointestinal anatomy and physiology. In Avian Physiology, pp 299-326. Ed. GC Whittow. New York: Academic Press.
Dieguez C \& Casanueva FF 2000 Ghrelin: a step forward in the understanding of somatotroph cell function and growth regulation. European Journal of Endocrinology 142 413-417.

Di Scala-Guenot D, Strosser M-T \& Miache P 1984 Characterization of somatostatin in peripheral and portal plasma in the chick: in vivo metabolism of somatostatin-28 and -14. Journal of Endocrinology 100 329-335.

Furuse M, Tachibana T, Ohgushi A, Ando R, Yoshimatsu T \& Denbow DM 2001 Intracerebroventricular injection of ghrelin and growth hormone releasing factor inhibits food intake in neonatal chicks. Neuroscience Letters 301 123-126.

Gaylinn BD, Harvey S \& Toogood AA 2000 Cloning of growth hormone-releasing hormone receptor and growth hormone secretagogue receptor from chicken. In International Symposium on Avian Endocrinology, Varanasi, India, Abstract 6.04. Ed. A Dawson. Varanasi, India: Banares Hindu University.

Geris KL, Hickey GH, Berghman LR, Visser TJ, Kuhn ER \& Darras VM 1998 Pituitary and extrapituitary action sites of the novel nonpeptidyl growth hormone (GH) secretagogue L-692,429 in the chicken. General and Comparative Endocrinology 111 186-196.

Geris KL, Hickey GJ, Vandergohte A, Kuhn ER \& Darras VM 2001 Synthetic growth hormone secretagogues control growth hormone secretion in the chicken at pituitary and hypothalamic levels. Endocrine 14 67-72.

Guan XM, Yu H, Palyha OC, McKee KK, Feighner SD, Sirinathsinghji DJ, Smith RG, Van der Ploeg LH \& Howard AD 1997 Distribution of mRNA encoding the growth hormone secretagogue receptor in brain and peripheral tissues. Molecular Brain Research 48 23-29.

Harvey S 1990 Thyrotropin releasing hormone: a growth hormone releasing hormone. Journal of Endocrinology 125 345-358.

Harvey S 1995 Growth hormone release: stimulatory hypothalamic control. In Growth Hormone, pp 97-113. Eds S Harvey, CG Scanes \& WH Daughaday. Boca Raton: CRC Press.

Harvey S 1999 GHRH: a growth hormone releasing hormone in birds? In Neural Regulation in the Vertebrate Endocrine System, pp 69-83. Eds PD Prasnada Rao \& RE Peter. New York: Kluwer Academic/Plenum.

Harvey S \& Scanes CG 1984 Comparative stimulation of growth hormone secretion in anaesthetized chickens by human pancreatic growth hormone-releasing factor (hpGRF) and thyrotropin-releasing hormone (TRH). Neuroendocrinology 39 314-320.

Hewson AK \& Dickson SL 2000 Systemic administration of ghrelin induces fos and egr-1 proteins in the hypothalamic arcuate nucleus of fasted and fed rats. Journal of Neuroendocrinology 17 1047-1049.

Hosoda K, Kojima M, Kangawa K, Hosoda H, Iwakura H, Son C, Matsuda J, Mori K, Ogawa Y, Akimizu T \& Nakao K 2000a cDNA cloning of mouse ghrelin and its tissue distribution. Proceedings of the 82nd Meeting of the Endocrine Society, Toronto, Canada, Abstract no. 22.

Hosoda H, Kojima M, Matsue H \& Kangawa K 2000b Purification and characterization of rat des-Gln ${ }^{14}$ ghrelin, a second endogenous ligand for the growth hormone secretagogue receptor. Journal of Biological Chemistry 275 21995-22000.

Howard AD, Feighner SD, Cully DF, Arena JP, Liberator PA, Rosenblum CI, Hamelin M, Hreniuk DL, Palyha OC, Anderson J, Paress PS, Diaz C, Chou M, Liu KK, McKee KK, Pong S-S, Chaung L-Y, Elbrecht A, Dashkevicz M, Heavens R, Rigby M, Sirinathsinghji DJS, Dean DC, Melillo DG, Patchett AA, Nargund R, Griffin PR, DeMartino JA, Gupta SK, Schaeffer JM, Smith RG \& Van der Ploeg LHT 1996 A receptor in pituitary and hypothalamus that functions in growth hormone release. Science $\mathbf{2 7 3}$ 974-977.

Hsu SM, Raine I \& Farge H 1981 Use of avidin-peroxidase complex $\mathrm{ABC}$ in immuno-peroxidase techniques: a comparison between $\mathrm{ABC}$ and unlabeled antibody AAP procedures. Journal of Histochemistry and Cytochemistry 29 577-580. 
Kamegai J, Tamura H, Shimizu T, Ishii S, Sugihara H \& Wakabayashi I 2000 Central effect of ghrelin, and endogenous growth hormone secretagogue, on hypothalamic peptide gene expression. Endocrinology 141 4797-4800.

Kojima M, Hosoda H, Date Y, Nakazato M, Matsuo H \& Kangawa K 1999 Ghrelin is a growth-hormone-releasing acylated peptide from stomach. Nature 402 656-660.

Kojima M, Hosoda H, Matsuo H \& Kangawa K 2001 Ghrelin: discovery of the natural endogenous ligand for the growth hormone secretagogue receptor. Trends in Endocrinology and Metabolism 12 118-122.

Korbonits M, Bustin SA, Kojima M, Jordan J, Adams EF, Lowe DG, Kangawa K \& Grossman AB 2001 The expression of the growth hormone secretagogue receptor ligand ghrelin in normal and abnormal human pituitary and other neuroendocrine tumors. Journal of Clinical Endocrinology and Metabolism 86 881-887.

Kuenzel WJ \& Masson M 1988 A Stereotaxic Atlas of the Brain of the Chick (Gallus domesticus). Baltimore \& London: Johns Hopkins University Press.

McKee KK, Palyha OC, Feighner SD, Hreniuk DL, Tan CP, Phillips MS, Smith RG, Van der Ploeg LHT \& Howad AD 1997 Molecular analysis of rat pituitary and hypothalamic growth hormone secretagogue receptors. Molecular Endocrinology 11 415-423.

MacNamee MC \& Sharp PJ 1989 The functional activity of hypothalamic 5-hydroxytryptamine neurones in broody bantam hens. Journal of Endocrinology 120 125-134.

Masuda Y, Tanaka T, Inomata N, Ohnuma N, Tanaka S, Itoh Z, Hosoda H, Kojima M \& Kangawa K 2000 Ghrelin stimulates gastric acid secretion and motility in rats. Biochemical and Biophysical Research Communications 276 905-908.

Mikami S-I 1985 Immunocytochemical localization of neuropepties in the neurohemal regions of the avian hypothalamus. In Neurosecretion and the Biology of Neuropeptides, pp 132-140. Ed. H Kobayashi. Tokyo: Springer Verlag.

Nakazato M, Murkami N, Date Y, Kojima M, Matsuoi H, Kangawa K \& Matsukura S 2001 A role for ghrelin in the central regulation of feeding. Nature 409 194-198.

Peino R, Baldelli R, Rodriguez-Garcia J, Rodriguez-Segade S, Kojima M, Kangawa K, Arvat E, Ghigo E, Diequez C \& Casanueva FF 2000 Ghrelin-induced growth hormone secretion in humans. European Journal of Endocrinology 143 R11-R14.

Ramesh R, Kuenzel WJ, Buntin JD \& Proudman JA 2000 Identification of growth-hormone- and prolactin-containing neurons within the avian brain. Cell and Tissue Research 299 371-383.
Robinzon B, Koike TI, Neldon HL \& Kinzler SL 1988 Distribution of immunoreactive mesotocin and vasotocin in the brain and pituitary of chickens. Peptides 9 829-833.

Seoane LM, Tovar S, Baldelli R, Arvat E, Ghigo E, Casanueva FF \& Dieguez C 2000 Ghrelin elicits a marked stimulatory effect on GH secretion in freely moving rats. European Journal of Endocrinology 143 R7-R9.

Shintani M, Ogawa Y, Ebihara K, Aizawa-Abe M, Miyanaga F, Takaya K, Hayashi T, Inoue G, Hosoda K, Kojima M, Kangawa K \& Nakao K 2001 Ghrelin, an endogenous growth hormone secretagogue, is a novel orexigenic peptide that antagonizes leptin action through the activation of hypothalamic neuropeptide Y/Y1 receptor pathway. Diabetes 50 227-232.

Takaya K, Ariyasu H, Kanamoto N, Iwakura H, Yoshimoto A, Harada M, Mori K, Komatsu Y, Usui T, Shimatsu A, Ogawa Y, Hosoda K, Akamizu T, Kojima M, Kangawa K \& Nakao K 2000 Ghrelin strongly stimulates growth hormone $(\mathrm{GH})$ release in humans. Journal of Clinical Endocrinology and Metabolism $\mathbf{8 5}$ 4908-4911.

Tennyson VM, Hou-Yu A, Nilaver G \& Zimmerman EA 1985 Immunocytochemical studies of vasotocin and mesotocin in the hypothalamo-hypophysial system of the chicken. Cell and Tissue Research 239 279-291.

Tolle V, Zizzari P, Tomasetto C, Rio M-C, Epelbaum J \& BluetPajot M-T 2001 In vivo and in vitro effects of ghrelin/motilinrelated peptide on growth hormone secretion in the rat. Neuroendocrinology 73 54-61.

Toogood AA, Harvey S, Thorner MO \& Gaylinn BD 1999 Cloning the chicken growth hormone secretagogue receptor. Proceedings of the 81st Annual Meeting of the Endocrine Society, San Diego, CA, Abstract p 382, no. 2-479.

Tschop M, Smiley DL \& Heiman ML 2000 Ghrelin induces adiposity in rodents. Nature 407 908-913.

Wren AM, Small CJ, Ward HL, Murphy KG, Dakin CL, Taheria S, Kennedy AR, Roberts GH, Morgan DGA, Ghatei MA \& Bloom SR 2000 The novel hypothalamic peptide ghrelin stimulates food intake and growth hormone secretion. Endocrinology 141 4325-4328.

Yasuda M 1980 The nucleus magnocellularis in chicken hypothalamus. In Biological Rhythms in Birds: Neural and Endocrine Aspects, pp 33-41. Ed. Y Takabe. Tokyo: Japanese Society Press.

Received in final form 10 September 2001 Accepted 19 September 2001 